\title{
URGENSITAS ASPEK KEPRIBADIAN BAGI GURU PAI
}

\author{
Oleh: \\ Hilyah Ashoumi \\ Universitas KH. A. Wahab Hasbullah Jombang \\ hilyahashoumi@gmail.com
}

\begin{abstract}
:
Education is an important factor in improving the quality of human life, especially improving the quality of learners to have a broad knowledge, noble character, and beneficial to life in society. This educator is teacher as the central figure of education, must be exemplary his morality beside that his scientific and academic skills. In addition, the teacher have to the responsibility, religion to educate the students to be the knowledgeable, and morals. Educators are as professionals that charge of planning and implementing the learning process, he is the person who seeks to guide, improve, perfect, and purify the students so that the heart becomes close to khaliqnya
\end{abstract}

Key Words: Kepribadian, Guru, PAI, Watak

\section{A. Pendahuluan}

Pendidikan memiliki peranan dominan dalam kehidupan manusia, dengan pendidikan hidup manusia menjadi berkualitas, khususnya peningkatan kualitas peserta didik untuk memiliki ilmu pengetahuan yang luas, berakhlak mulia dan bermanfaat bagi kehidupan di masyarakat. Inilah sebenarnya tugas utama seorang pendidik. Jadi yang dinamakan dengan pendidikan pada hakikatnya tidak hanya sekedar memberikan ilmu pengetahuan bagi anak didik. Namun, lebih jauh dari itu harus dibarengi dengan pembentukan akhlak, mental, etika dan budi pekerti. Dengan demikian, diharapkan anak didik tidak hanya pandai di bidang akademis, tetapi juga berakhlak mulia.

Sudah kita ketahui bersama bahwa tujuan pendidikan agama Islam, adalah upaya menghantarkan peserta didik berakhlakul karimah, sehingga mampu membedakan benar dan salah, memilih sesuatu yang bermanfaat atau sebaliknya merugikan. Atau mudahnya tugas utama seorang pendidik agar dia mampu mendidik anak didiknya, dengan berusaha menumbuh kembangkan potensi peserta didik agar dalam sikap hidup, tindakan dan pendekatannya terhadap ilmu pengetahuan diwarnai oleh nilai etik religius, atau senantiasa berakhlakul karimah. Karena dalam pandangan

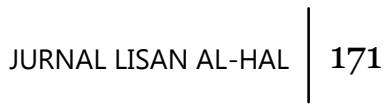


Islam bahwa pendidikan merupakan hal yang sangat utama untuk membentuk manusia berakhlakul karimah.

Guru sebagai figur sentral dalam pendidikan, haruslah dapat diteladani akhlaknya di samping kemampuan keilmuan dan akademisnya. Selain itu guru haruslah mempunyai tanggung jawab dan keagamaan untuk mendidik anak didiknya menjadi orang yang berilmu dan berakhlak.

\section{B. Kepribadian}

\section{Pengertian Kepribadian}

Karakter adalah bentuk organisasi dari kehidupan perasaan, pengenalan, pengenalan dan kehendak yang diarahkan pada sistem nilai, dan diekspresikan dengan relatif konsekwen pada pencapaian nilai-nilai yang ingin dicapai. ${ }^{1}$ Disisi lain karakter bernilai ethis, suatu karakter yang sebagai keseluruhan memenuhi norma-norma kesusilaan, kita nyatakan sebagai karakter yang baik. Karakter yang formal kuat, belum tentu baik. Karakter yang kuat misalnya dapat diarahkan untuk mencapai kekuasaan tanpa mengingat nilai-nilai lainnya. Dalam hal ini karakter tersebut memang kuat, tetapi tidak baik. Jadi karakter juga mempunyai aspek ethis. Itulah yang menentukan nilai pribadi manusia. Karakter mempunyai arti keseluruhan sifat-sifat individual manusia, tetapi untuk menyatakan keseluruhan sifat-sifat psikis manusia kita lebih tepat menggunakan istilah kepribadian. Jadi karakter mempunyai arti yang lebih sempit seperti yang lebih sempit sebagaimana telah dijelaskan diatas. Kepribadian merangkum tempramen, karakter, bakat kemampuan dan sebagainya

Kata kepribadian bukan kata asing dalam kehidupan sehari-hari. Walaupun kata kepribadian telah menjadi kosa kata umum dalam percakapan sehari-hari, tidak jarang dari kita yang belum paham benar pengertian kata kepribadian secara etimologi maupun menurut pendapat para ahli. Kepribadian adalah satu totalitas terorganisis dari disposisidisposisi psikhis manusia yang individuil, yang memberi kemungkinan untuk memperbedakan ciri-cirinya yang umum dengan pribadi lainnya. ${ }^{2}$

Satu totalitas itu bukan hanya merupakan satu penjumlahan melulu dari bagian-bagian, tapi merupakan satu kesatuan yang tidak dapat dibagibagikan, tapi merupakan satu kesatuan yang tidak dapat dipisah-pisahkan satu dengan lainnya. Kepribadian ini merupakan satu struktur totalitas yang mempunyai aspek-aspek yang saling berhubungan satu dengan yang lainya.

\footnotetext{
${ }^{1}$ Kartini Kartono. Teori Kepribadian (Bandung: Alumni, 1980) hlm. 50.

2 Ibit., hlm. 10.
}

172 JURNAL LISAN AL-HAL 
Disposisi itu ialah kesediaan kecenderungan-kecenderuangan untuk bertingkah laku tertentu, yang sifatnya lebih kurang tetap/konstan, dan terarah pada tujuan tertentu (bahasa latinnya disposition yaitu ketentuan, ketetapan). Sungguhpun di dalam konteksnya kepribadian itu akan selalu berkembang dan bersifat dinamis, namun ada disposisidiaposisi psikhis pokok atau dasar yang bersifat konstan. Individuil, ini berarti bahwa setiap orang itu mempunyai kepribadiannya sendiri yang khas, yang tidak identik dengan orang lain. Yang tidak dapat diganti atau disubsititusikan oleh orang lain. Jadi ada ciri-ciri atau sifat-ifat individuil pada aspek-aspek pshikisnya, yang bisa membedakan dirinya dengan orang lain.

Dalam literatur ilmu jiwa kata kepribadian secara etimologi berasal dari kata personality (bahasa Inggris) ataupun persona (bahasa latin), yang berarti kedok atau topeng. Yaitu tutup muka yang sering dipakai oleh pemain panggung, yang maksudnya untuk menggambarkan perilaku, watak atau pribadi seseorang. ${ }^{3}$

Sementara itu Drs. Suparlan Suryapratondo mengatakan, kata personality sebagai padanan kata kepribadian, selain berarti kedok atau topeng juga berarti menembus (personare). Maksudnya pemain sandiwara itu mlalui kedoknya berusaha keluar untuk mengekpresikan satu bentuk gambaran manusia tertentu. ${ }^{4}$

Dalam al-Qur'an terdapat banyak ayat yang menyebutkan tentang nafs yang sering diterjemahkan sebagai jiwa, pribadi tau diri sendiri. Ayatayat itu antara lain:

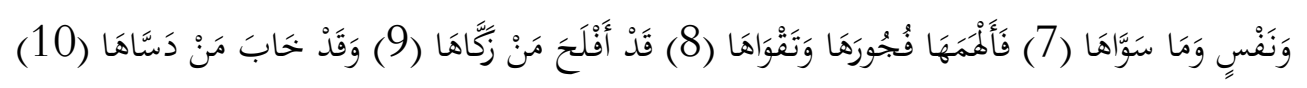

$$
\text { [11-7/الشمس }
$$

"Dan jiwa (pribadi) serta penyempurnaan (ciptaanya). Maka Allah mengilhamkan kepada jiwa (jalan) kefasikan dan ketakwaannya. Sesungguhnya beruntunglah orang yang mensucikan jiwa itu (diri pribadinya). Dan sesungguhnya rugilah orang yang mengotorinya". (Q.s Asy-Syam 7-10)

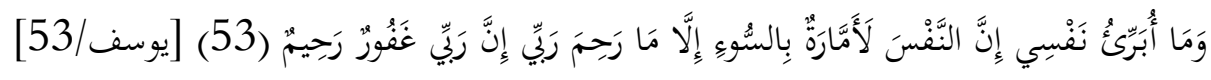

"Dan aku tidak membebaskan diri pribadiku (jiwaku) dari kesalahan,

${ }^{3}$ Agus Sujanto, op. cit., hlm.10. hlm. 108

${ }^{4}$ Suparlan Suryapratondo. Ilmu Jiwa Kepribadian (Jakarta: Paryu Barkah, 1980), 
karena sesungguhnya nafsu itu selalu menyuruh kepada kejahatan, kecuali bila Tuhanku memberi rahmat. Sesungguhnya Tuhan Maha Pengampun lagi Maha Penyayang". (Q.s Yusuf : 53)

Kepribadian juga sering diartikan dan dihubungkan dengan ciri-ciri tertentu yang menonjol pada diri individu. Menurut pengertian seharihari, menunjuk kepada bagaimana individu tampil dan menimbulkan kesan bagi individu lainnya. Kepribadian yang dimaksud adalah hanya menunjuk terbatas kepada ciri-ciri yang dapat diamati saja, dan mengabaikan kemungkinan bahwa ciri-ciri ini bisa berubah tergantung pada situasi keliling, dan kepribadian yang dimaksud ini bersifat evaluatif (menilai). Menurut Gordon Allport kepribadian sebagai sesuatu yang terdapat dalam diri individu yang membimbing dan dan memberi arah kepada seluruh tingkah laku individu yang bersangkutan. Allport merumuskan tentang kepribadian adalah suatu kesatuan organisasi yang dinamis sifatnya dari system psikofisis individu yang menentukan kemampuan penyesuaian diri yang unik sifatnya terhadap lingkungannya. ${ }^{5}$

Istilah dinamis menunjukkan adanya perubahan dalam kepribadian, menekankan bahwa perubahan dalam kualitas perilaku seseorang. Istilah susunan mengandung arti bahwa kepribadian tidak dibangun dari berbagai ciri yang satu ditambahkan pada yang lain begitu saja, melainkan ciri-ciri ini saling berkaitan. Istilah sistem psikofisik adalah kebiasaan, sikap, nilai, keyakinan, keadaan emosional, keadaan dan motif yang bersifat psiklogis tetapi mempunyai dasar fisik dalam kelenjar, saraf, dan kedaan fisik secaa umum. Sistem psikofisik merupakan kekuatan motivasi yang menentukan jenis penyesuaian seseorang. ${ }^{6}$

Kepribadian bersifat hakiki individu yang tercemin pada sikap dan perbuatannya yang membedakan dirinya dari yang lain. Mc Leod (1989) mengartikan kepribadian (personality) sebagai sifat khas yang dimiliki seseorang. Menurut tinjuan psikologi, kepribadian pada prinsipnya adalah susunan atau kesatuan antara apek perilaku mental (pikiran, perasaan, dan sebagainya) dengan aspek behavioral (perbuatan nyata). Aspek-aspek ini berkaitan secara fungsional dalam diri seorang individu, sehingga membuatnya bertingkah laku secara khas dan tetap (Reber, 1988).

Kepribadian adalah faktor yang sangat berpengaruh terhadap keberhasilan seorang guru sebagai pengembang sumberdaya manusia, disamping ia berperan sebagai pembimbing dan pendidik, guru juga

${ }^{5}$ Kartini Kartono, op,cit,. hlm. 10.

${ }^{6}$ Elizabeth B. Hurlock, Perkembangan Anak (Jakarta : Erlangga, 1993), hlm. 237.

$174 \mid$ JURNAL LISAN AL-HAL 
berperan sebagai panutan, karena figur sentral dalam dunia pendidikan, khususnya dalam proses belajar mengajar (PBM) adalah guru, maka setiap guru diharapkan memiliki karakteristik (ciri khas) kepribadian yang ideal sesuai dengan persyaratan yang bersifat psikologis-pedagogis. Pemapanan kepribadian guru menuju guru profesional adalah salah satu cara yang tepat untuk bangkit dalam keterbenaman.

Berdasarkan pendapat mengenai kepribadian diatas dapat diambil pengertiaan sebagai berikut:

a. Kepribadian merupakan suatu kebulatan yang terdiri dari aspek jasmani dan apek rohani.

b. Kepribadian itu bersifat dinamis dalam hubungannya dengan kehidupan sosial

c. Kepribadian seseorang itu khas, unik, berbeda dengan orang lain.

Dapat disimpulkan bahwa karakteristik kepribadian guru Pendidikan Agama Islam adalah keadaaan sifat, minat, tabiat, dan kelakuan yang dimiliki guru Pendidikan Agama Islam kepada anak didiknya.

\section{Aspek-Aspek Kepribadian}

Kepribadian itu mengandung pengertian yang sangat kompleks yang terdiri dari bermacam-macam aspek, baik fisik maupun psikis yaitu:

a. Sifat-sifat kepribadian (personality traits). Sifat dalam istilah psikologi berarti ciri-ciri tingkah laku yang tetap (hampir tetap) pada seseorang. Sifat merupakan kecenderungan-kecenderungan umum pada seorang individu untuk menilai situasi-situasi dengan cara-cara tertentu dan bertindak sesuai dengan penilaian itu. Sifat merupakan ciri-ciri tingkah laku atau perbuatan yang banyak dipengaruhi oleh faktor-faktor dalam diri manusia seperti pembawaan, minat, konstitusi tubuh dan cenderung bersifat tetap atau stabil.

b. Intelegensi. Kecerdasan aau intelegensi merupakan aspek kepribadian yang penting. Termasuk di dalamnya kewaspadaan, kemampuan belajar, kecepatan befikir, kesanggupan untuk mengambil keputusan yang tepat, kepandaian menangkap dan mengelola kesan-kesan atau masalah, dan kemampuan mengambil keputusan.

c. Pernyataan diri dan cara menerima kesan-kesan. Termasuk kedalam aspek ini adalah: kejujuran, berterus terang, menyelimuti diri, pendedam, tidak dapat menyimpan rahasia, mudah melupakan kesankesan, dan lain-lain.

d. Kesehatan. Kesehatan jasmani atau bagaimana kondisi fisik sangat erat hubungannya dengan kepribadian seseorang.

e. Bentuk tubuh. Termasuk besarnya, beratnya, dan tingginya 
f. Sikapnya terhadap oranng lain. Sikap seseorang terhadap orang lain tidak terlepas dari sikap orang itu terhadap dirinya sendiri. Bermacammacam sikap yang ada pada seseorang turut menentukan kepribadianya.

g. Pengetahuan. Pengetahuan yang dimiliki seseorang memainkan peranan penting di dalam pekerjaan/ jabatannya, cara-cara penerimaan dan penyesuain sosialnya, pergaulanya, dan sebagainya.

h. Keterampilan. Keterampilan seseorang dalam mengerjakan sesuatu, sangat mempengaruhi bagaiman cara orang itu bereaksi terhadap situasi-situasi tertentu, misalnya: kecakapan mengemudikan mobil, kecekatan dalam mengerjakan atau membuat pekerjaan-pekerjaan tangan.

i. Nilai-nilai (values). Nilai-nilai yang ada pada seseorang dipengaruhi oleh adad istiadat, etika, kepercayaan dan agama yang dianutnya. Semua itu mempengaruhi sikap, pendapat, dan pandangan seseorang yang selanjutnya tercermin dalam cara-cara kita bertindak dan bertingkah laku.

j. Penguasaan dan kuat-lemahnya perasaan. Keadaan perasaan yang berbeda-beda pada seseorang sangat mempengaruhi kepribadianya.

k. Peranan (roles). Peranan atau roles disini adalah kedudukan atau posisi seseorang di dalam masyarakat di mana ia hidup. Termasuk dalam peranan ini ialah tempat dan jabatannya, macam pekerjaannya, dan tinggi rendahnya kedudukan itu.

1. The self. The self adalah individu sebagaimana diketahui dan dirasakan oleh individu itu sendiri, ia terdiri dari self picture, yaitu aspek-aspek yang disadari dan pandangan individu tentang dirinya sendiri yang tidak disadari. Dengan kata lain the self adalah anggapan dan perasaan individu tentang siapa, apa, dan di mana sebenarnya ia berada.

\section{Faktor-Faktor Yang Mempengaruhi Kepribadian}

Kepribadian itu selalu mengalami perubahan-perubahan. Tetapi didalam perkembangan itu makin terbentuklah pola-polanya yang tetap khas, sehingga merupakan ciri-ciri yang unik bagi setiap individu. Faktorfaktor yang mempengaruhi kepribadian seseorang menurut Afifuddin ada dua hal yaitu: faktor dari dalam dan faktor dari luar. Yang dimaksud faktor dari dalam yaitu segala sesuatu yang dibawa anak sejak lahir. Faktor dari dalam ini meliputi pembawaan phisik dan pembawaan kewajiban (psikis). Sedangkan dari faktor luar adalah segala sesuatu yang ada diluar manusia, seperti lingkungan sekolah, keluarga, pergaulan, masyarakat, dan 
sebagainya. ${ }^{7}$ Faktor-faktor yang mempengaruhi perkembangan dan kepribadian itu dapat dibagi sebagai berikut:

Pertama, Faktor biologis. Yaitu faktor yang berhubungan dengan jasmani, atau sering kali pula disebut faktor biologis. Faktor ini berasal dari keturunan atau pembawaan yang dibawa sejak lahir, yang mempunyai peran pada beberapa unsur kepribadian dan mempengaruhi tingkah laku seseorang.

Kedua, Faktor sosial. Yang dimaksud dengan faktor sosial di sini adalah masyarakat; yakni manusia-manusia lain disekitar individu yang mempengaruhi individu yang bersangkutan. Termasuk kedalam faktor sosial ini adalah tradisi-tradisi, adat istiadat, peraturan-peraturan, bahasa, dan sebagainya yang berlaku di dalam masyarakat.

Ketiga, Faktor kebudayaan. Sebenarnya faktor kebudayaan itu termasuk faktor sosial, karena faktor sosial tumbuh dan berkembang di dalam masyarakat. Perkembangan dan pembentukan kepribadian pada masing-masing orang tidak dapat dipisahkan dari kebudayaan masyarakat dimana anak dibesarkan. Karena setiap kebudayaan mempunyai nilai yang harus dijunjung tinggi oleh manusia yang hidup dalam kebudayaan tersebut. Mentaati dan mematuhi nilai dalam kebudayaan itu menjadi kewajiban bagi anggota masyarakat kebudayaan, disamping itu juga harus mempunyai kepribadian yang selaras dengan kebudayaan yang berlaku dalam masyarakat itu. Dari uraian tersebut diatas dapat disimpulkan bahwasanya pribadi seseorang tumbuh dan berkembang atas dua kekuatan, yaitu kekuatan dari dalam yang berupa faktor biologi dan kekuatan dari luar yang berupa faktor sosial dan faktor kebudayaan.

\section{Pengukuran Kepribadian}

Dalam membicarakan pengukuran kepribadian, tidak terlepas dari pengukuran psikologis. Sebab kepribadian merupakan salah satu atribut psikologis yang dapat diukur dengan suatu alat ukur. Alat ukur psikologis ada bermacam-macam; misalnya tes minat, tes bakat, tes intelegensi dan tes kepribadian. Dalam bukunya Sumadi Suryabrata menurut atributnya tes psikologis dibagi menjadi empat yaitu: a) Kepribadian diukur dengan tes kepribadian; b) Intelegensi diukur dengan tes intelegensi; c) Potensi intelektual diukur dengan tes potensi intelektual; dan d) Hasil belajar diukur dengan tes hasil belajar

Untuk dapat mengukur kepribadian seseorang dapat menggunakan

${ }^{7}$ Afifuddin. Psikologi Pendidikan Anak Usia SD (Solo: Harapan Massa, 1988), hlm. 
beberapa cara lain; dengan mengamati bagaimana individu mengadakan hubungan antar manusia disekitar; dengan wawancara dengan individu itu sendiri atau orang-orang yang berada disekitar individu, dengan mengajukan daftar pertanyaan (koesioner), atau melalui inventory (pelaporan diri) yaitu dengan menjawab pertannyaan atau melengkapi kalimat tentang diri pribadi individu sesuai dengan dirinya. Dengan tes proyeksi misalnya dengan menggambar atau bercerita untuk memproyeksikan dirinya.

\section{Guru Pendidikan Agama Islam}

\section{Pengertian Guru Pendidikan Agama Islam}

Dalam pengertian yang sederhana guru adalah orang yang memberi ilmu kepada anak didik. Tetapi dalam pandangan masyarakat, guru adalah orang yang melaksanakan pendidikan di tempat-tempat tertentu, tidak mesti di lembaga formal, tetapi juga di masjid, mushola, di rumah dan sebagainya. Menurut Drs. A Muri Yusuf mengatakan bahwa guru atau pendidik dalam satu situasi pendidikan mencapai tujuan pendidikan. Individu yang mampu tersebut adalah orang dewasa yang bertanggung jawab, orang yang sehat jasmani dan rohani dan individu yang mampu berdiri sendiri dan mampu menanggung resiko dari segala perbuatan. ${ }^{8}$

Menurut para ahli pendidikan berpendapat: Guru adalah seseorang yang menyebabkan orang lain mengetahui atau mampu melaksanakan sesuatu yang memberikan pengetahuan atau keterampilan kepada orang lain. Guru adalah tenaga pendidik yang tugas utamanya mengajar, dalam arti mengembangkan ranah cipta, rasa, dan karsa siswa sebagai implementasi konsep ideal mendidik. ${ }^{9}$

Dari beberapa definisi diatas dapatlah diambil kesimpulan bahwa guru pendidikan agama Islam itu bukanlah hanya sekedar pemberi ilmu pengetahuan kepada murid-muridnya di dalam kelas. Tetapi merupakan seorang tenaga profesioal yang dapat menjadikan, mampu merencanakan, menganalisa, dan menyimpulkan masalah yang dihadapi atau seorang pendidik yang bertugas mengajarkan ajaran Islam dan membimbing anak didik kearah pencapaian kedewasaan serta terbentuknya kepribadian anak didik yang Islami sehingga terjadi keseimbangan, kebahagian dunia

${ }^{8}$ A. Muru Yusuf. Pengantar Ilmu Pendidikan. (Jakarata Timur: Ghalia Indonesia, 1982), hlm 54

9 Muhibbin Syah. Psikologi Pendidikan Dengan Pendekatan Baru. (Bandung: PT Remaja Rosdakarya, 2003), hlm. 256

178 JURNAL LISAN AL-HAL 
dan akhirat.

Oleh karena itu guru pendidikan agama Islam dituntut untuk memahami bagaimana karakteristik (ciri khas) kepribadian yang diperlukan sebagai anutan para siswanya. Karakteristik kepribadian yang berkaitan dengan keberhasilan guru pendidikan agama Islam dalam menggeluti profesinya adalah meliputi: 1) fleksibilitas kognitif; 2) keterbukaan psikologis. ${ }^{10}$ Selanjutnya akan dijelaskan tentang fleksibilitas kognitif.

Fleksibilitas Kognitif (keluwesan ranah cipta) merupakan kemampuan berfikir yang diikuti dengan tindakan secara simultan dan memadai dalam situasi tertentu. Kebalikannya adalah frigiditas kognitif atau kekakuan ranah cipta yang ditandai dengan kekurangmampuan dalam berfikir dan bertindak yang sesuai dengan situasi yang sedang dihadapi. Guru yang fleksibel biasanya ditandai dengan keterbukaan berfikir dan beradaptasi. Selain itu ia juga mempunyai resistensi (daya tahan) terhadap ketertutupan ranah cipta yang prematur dalam pengamatan dan pengenalan. Ketika mengamati dan mengenali suatu obyek atau situasi tertentu, seorang guru yang fleksibel selalu berfikir kritis. Berfikir kritis ialah berfikir dengan penuh pertimbangan akal sehat yang dipusatkan pada pengambilan keputusan untuk mencapai atau menggingkari sesuatu, dan melakukan atau menghindarkan sesuatu (Heger \& Kaye, 1990).

Dalam proses belajar mengajar, fleksibilitas kognitif guru terdiri atas tiga dimensi yakni: 1) Dimensi karakteristik kepribadian guru; 2) Dimensi sikap kognitif guru terhadap siswa; dan 3) Dimensi sikap kognitif guru terhadap materi pelajaran dan metode mengajar

\section{Urgensi Kompetensi Guru PAI}

Para tokoh pemikir Islam zaman klasik telah banyak menulis tentang pendidikan termasuk di dalamnya kompetensi pendidik menyangkut hak, kewajiban, etika ataupun sifat. Diantaranya adalah AlQurtubi dalam kitabnya Jami' bayan al-'ilm wa fadlih, dan Al-Ghazali dalam fatihat al-'ulum dan ihya' al-'ulum al-Din. Demikian pula para ulama pendidikan moderen seperti Gilbert $H$. Hunt dan al-Abrashi. Dalam membahas sifat-sifat pendidik, Gilbert $\mathrm{H}$. Hunt menegaskan sifat-sifat sebagaimana berikut: "1) Antusias. 2) Stimulatif. 3) Hangat. 4) Pekerja Keras. 5) Toleran. 6) Sopan. 7) Bijaksana. 8) Bisa Dipercaya. 9) Fleksibel dan Mudah Menyesuaikan Diri. 10) Demokrasi. 11) Tidak Semata Mencari

10 ibid, hlm 226-229. 
Reputasi Pribadi. 12) Bertanggungjawab. 13) Penuh Harapan Bagi Siswa."11 Semua sifat tersebut bisa dipelajari serta bisa dikembangkan lewat pendidikan.

Jika pakar pendidikan modern mengklasifikasikan sifat-sifat yang harus dimiliki oleh guru sebagaimana diatas maka pakar pendidikan Islam yang diwakili oleh Al-Abrashi dalam makalah ini menyatakan bahwa sifatsifat yang harus dimiliki oleh seorang guru adalah sebagai berikut: "1) Zuhud dan mengajar karena Allah. 2) Kesucian pendidik. 3) Ikhlas. 4) Bijaksana. 5) Berpenampilan kharismatik dan tenang. 6) Memahami kejiwaan anak, cita-cita, dan pemikirannya agar tidak salah bersikap kepadanya. 7) Menguasai materi pelajaran dan terus mengembangkan penelitian." 12

Pendidik memiliki derajat yang tinggi dan terhormat, oleh sebab itu memiliki kewajiban yang setara dengan derajat tersebut. Pendidik yang zuhud, dalam mengajar tidak mengaharapkan upah duniawi, melainkan dalam menyebarkan ilmu hanya mengharapkan ridla dan karena Allah semata. Kondisi seperti ini telah berjalan lama dalam tradisi pendidikan Islam khususnya di pesantren. Mereka para pendidik tidak menerima upah. Tradisi inilah yang tidak akan didapati pada lembaga pendidikan lainnya, terlebih lembaga pendidikan Umum.

Dalam hal kesucian pendidik, hendaklah pendidik suci lahiriyah dan batiniyah dengan menjauhi dosa-dosa dan sifat tercela yang melanggar syariat agama. Aspek lainnya adalah Ikhlas. Ikhlas secara dasar hendaknya ditunjukkan dengan berbuat sesuai dengan komitmennya, dan berkata sesuai dengan perbuatan, dan tidak segan mengatakan tidak tahu jika memang benar tidak tahu. Pendidik yang sejati seharusnya selalu merasa perlu untuk menambah wawasan keilmuannya, sehingga tidak malu menempatkan dirinya pada posisi menjadi siswa pada saat tertentu ketika ingin mencari kebenaran (belajar). Pendidik menghargai waktu siswa, bersikap lemah lembut, dan bertanggung jawab terhadap prilaku dan perkataan pendidik itu sendiri. Oleh karenanya diperlukan sifat bijaksana, kebijaksanaan biasanya berhubungan dengan kedewasaan.

Dalam hal ini hendaknya dapat memberlakukan siswanya seperti anaknya sendiri. Maka seyogyanya untuk sepenuhnya bisa melakukan hal ini pendidik harus sudah berkeluarga. Bahkan dianjurkan mendidik anak didik sebagaimana anaknya sendiri, sehingga dengan demikian tercapailah

11 Ibid, hlm. 113.

${ }^{12}$ M. Atiyah al-Abrasyi, Dasar-Dasar Pokok Pendidikan Islam (terj). (Jakarta: Bulan Bintang, 1993), hlm. 137-141.

$180 \mid$ JURNAL LISAN AL-HAL 
keharmonisan belajar mengajar. Kedewasaan pendidik juga dapat membantu dalam memahami kejiwaan anak, cita-cita, dan pemikirannya sehingga mampu mengusai materi dan menyampaikan dengan sesuai dengan prinsip kejiwaan.

Mengasihi anak didik seperti menyayangi anak sendiri, menurut alGhazali merupakan tugas yang pertama. Hal ini disandarkan pada sabda Rasulullah :

$$
\text { إنما أنا لكم مثل الوالد لولده }
$$

"Sesungguhnya saya bagimu adalah seperti orang tua kepada anaknya"13

Di samping itu menurut al-Ghazali guru yang baik adalah sebagai berikut: Pertama, jika praktek mengajar dan penyuluhan sebagai keahlian dan profesi dari seorang guru, maka sifat terpenting yang harus dimilikinya adalah rasa kasih sayang. Kedua, karena mengajarkan ilmu merupakan kewajiban agama bagi setiap orang yang alim (berilmu), maka seorang guru tidak boleh menuntut upah atas jerih payahnya mengajar itu.

Ketiga, seorang guru yang baik hendaknya berfungsi juga sebagai pengarah dan penyuluh yang jujur dan benar dihadapan murid-muridnya. Keempat, dalam kegiatan seorang guru hendaknya menggunakan cara yang simpatik halus dan tidak menggunakan kekerasan, cacian, makian dan sebagainya. Kelima, seorang guru yang baik juga harus tampil sebagai teladan atau panutan yang baik di hadapan murid-muridnya.

Keenam, seorang guru yang baik juga harus memiliki prinsip mengakui adanya perbedaan potensi yang dimiliki murid secara individual, dan memperlakukannya seperti sesuai dengan tingkat perbedaan yang dimiliki muridnya itu. Ketujuh, guru disamping memahami perbedaan tingkat kemampuan juga kecerdasan muridnya juga memahami bakat, tabi'at dan kejiwaan muridnya sesuai dengan tingkat perbedaan usianya. Kedelapan, guru yang berpegang teguh pada prinsip yang diucapkannya, serta berupaya untuk merealisasikannya sedemikian rupa. ${ }^{14}$

Sebagaimana al-Ghazali, Jhon K. Roth memberikan Kriteria guru yang baik sebagai berikut: Pertama, Memiliki pemikiran bahwa Mengajar adalah sebuah tugas untuk menjadi orang tua siswa dalam batas-batas kompetensi keguruan. Kedua, Memiliki sikap positif, tidak sinis pada pekerjaannya apalagi dengan alasan indeks gaji rendah. Sikap sini juga tak boleh dilakukan kepada siswanya, entah siswa nakal atau pun lemah pada

${ }^{13}$ Imam al-Ghazali, Ihya' Ulumuddin, Juz I, Terj. Moh. Zuhri (Semarang: Asy-Syifa': 2003), hlm. 171.

${ }^{14}$ Jamali Sahrodi, dkk, Membedah Nalar Pendidikan Islam, hlm. 21-24. 
pelajarannya. Ketiga, Selalu mencoba untuk memotivasi siswa untuk hidup mandiri dan percaya diri. Keempat, Berani menyusun tujuan pembelajaran yang tinggi dan berusaha untuk mencapainya. Kelima, tidak memiliki waktu yang cukup untuk bersantai, waktunya habis untuk memberikan pelayanan bagi siswanya. Keenam, harus bisa menciptakan jarak antara kemampuannya dengan kemampuan siswanya. Ketujuh, tidak percaya penuh dengan evaluasi siswanya terhadap kinerja dirinya. Kedelapan, senantiasa mendengarkan permintaan, saran dan kritik siswanya.

Dengan berkembangnya ilmu pengetahuan dan teknologi (IPTEK) saat ini maka kompetensi yang dimiliki pendidik pun juga tidak boleh tidak dikembangkan atau hanya statis pada pengetahuan yang ia miliki saat ini, karena akan berdampak tidak baik apabila pendidik hanya mengulang-ulang pengetahuan yang sama sekalipun siswanya berbeda.

Jeanne Ellis Ormrod dalam bukunya menjelaskan bahwa sangatlah penting bagi pendidik memotivasi anak didiknya untuk selalu belajar dan berkembang tetapi perlu disadari oleh pendidik sendiri hal yang sama juga perlu ia lakukan. Berdasarkan riset yang telah ia uji maka ia berani memberikan strategi agar pendidik dapat mengembangkan kompetensi yang ia miliki: 15

Pertama, melanjutkan sekolah atau kursus yang berhubungan dengan pendidikan keguruan. Mengikuti kursus atau kuliah tambahan mengenai mengajar adalah cara yang paling mantap untuk tetap seirama dengan perspektif-perspektif teoritis dan riset-riset mutakhir mengenai praktik pengajaran. Secara umum, layanan pendidikan keguruan dan perkembangan profesional yang dilakukan sambil bekerja sungguhsungguh mampu memperbaiki efektivitas mengajar.

Kedua, mendalami mata pelajaran yang di-ampu. Ketika kami mempelajari para guru yang efektif- misalnya, guru-guru yang menerapkan pendekatan yang fleksibel dalam mengajar, yang membantu para siswanya memiliki pemahaman yang menyeluruh mengenai topik yang sedang dibahas, dan yang menampilkan antusiasme yang nyata terhadap mata pelajaran yang diajarkan- kami umumnya mendapati para guru yang sungguh-sungguh memahami mata pelajaran yang diampunya dengan sangat baik.

Ketiga, belajar secara contineu mengenai strategi-strategi pembelajaran yang tepat guna untuk pelajaran yang di-ampu. Selain mengetahui strategi mengajar secara umum, juga akan sangat membantu

15 Jeanne Ellis Ormrod, Educational psycology Developing Learned, Terj. Wahyu Indianti (Jakarta: Erlangga, 2008), hlm. 17-21.

182 JURNAL LISAN AL-HAL 
jika anda mengembangkan strategi-strategi spesifik terkait mata pelajaran yang anda ampu, guru yang efektif umumnya memiliki banyak strategi mengajar, dapat mengantisipasi, dan menangani kesulitan-kesulitan yang akan dihadapi para siswanya, termasuk kesalahan-kesalahan yang mungkin dilakukan para siswanya, dalam proses pengasaan keterampilan dan pengetahuan tertentu. Beberapa guru menggunakan diari atau metode-metode pencatatan lainnya untuk merekam strategi-strategi yang mereka buat dan kembangkan dalam situasi-situasi khusus dan menggunakan kembali catatan-catatan tersebut manakala dibutuhkan.

Keempat, selalu memiliki kepercayaan bahwa pendidik mampu memberi perbedaan berarti bagi keberlangsungan kehidupan anak didiknya. Lebih mudah mempelajari suatu materi bagai anak didik, saat mereka yakin mampu mempelajarinya. Dengan kata lain, jika mereka memiliki efikasi dirit16. Harusnya pendidik pun memiliki hal yang sama. Dengan kepercayaan bahwa pendidik mampu mendidik dengan baik, pendidik juga akan mampu untuk menghadapi keraguan-keraguan yang terkadang muncul. Anak didik yang memiliki nilai-nilai yang gemilang umumnya memiliki guru-guru yang yakin bahwa mereka sebagai guru mampu melakukan yang terbaik bagi anak didiknya.

Kelima, selalu bersedia dengan kesadaran diri melakukan refleksi dan mengkritisi praktik-praktik pembelajaran pendidik sendiri. Guru-guru yang efektif mengajar secara reflektif (reflektive teaching) ${ }^{17}$ dan berusaha mendorong siswa untuk berpikir kritis (critical thinking) ${ }^{18}$ mengenai mata pelajaran yang diberikan, guru pun harus berpikir kritis, tentang alasan siswa berperilaku tertentu dan mengapa siswa mendapat prestasi pada tingkat tertentu serta bagaimana prilaku peserta didik dan prestasi mereka dipengaruhi oleh praktik mengajar kita. Keenam, Riset terhadap cara mengajar pendidik sendiri. Guru yang baik akan melakukan suatu riset tindakan (action research $)^{19}$ terhadap permasalahan yang terjadi di kelas atau di sekolah, hal ini merupakan cara efektif untuk perkembangan siswa. Ketujuh, mempelajari kebudayaan di daerah tempat pendidik

16 Keyakinan yang dimiliki seseorang bahwa dirinya mampu menjalankan tugas tertentu atau meraih sasaran tertentu.

17 Pengujian dan kritik yang dilakukan secara rutin dan berkelanjutan oleh guru terhadap asumsi dan strategi mengajarnya sendiri, serta revisi terhadap asumsi atau strategi pengajaran tersebut sebagaimana yang dipandang perlu untuk meningkatkan pembelajaran dan perkembangan para siswa.

18 Proses mengevaluasi keakuratan dan nilai dari informasi dan alur penalaran.

19 Riset yang dilaksanakanoleh guru dan staf sekolah yang lain untuk membahas isu-isu dan permasalahan-permasalahan dalam sekolah atau kelas mereka. 
mengajar. Dengan mengetahui kebudayaan setempat, sehingga dapat meyakinkan anak didik, bahwasanya guru merupakan bagian dari masyarakat di tempat ia mengajar.

Adapun tugas guru Pendidikan Agama Islam meliputi empat hal: Pertama, tugas profesi. Dalam tugas ini seorang mempuyai tugas untuk mengajar, mendidik, melatih dan menilai atau mengevaluasi proses dan hasil belajar mengajar. Kedua, tugas keagamaan. Tugas guru dalam hal ini mempunyai tanggung jawab untuk melakukan amar ma'ruf nahi munkar, karena dalam hal ini seorang guru memiliki peran sebagai da'i. Ketiga, tugas kemanusiaan. Guru dituntut memiliki karakter positif yang dapat diteladani oleh para peserta didik. Berhubung dalam tugas ini guru berperan sebagai pengganti orang tua di rumah. Keempat, tugas kemasyarakatan. Sebagai guru agama di sekolah, tentunya gelar itu akan terbawa dalam kehidupan di masyarakat. Kedudukan guru agama di masyarakat begitu mulia dan dimuliakan, maka wajar seorang guru agama harus selalu siap untuk menjadi pemimpin agama. Dari hal inilah, maka seorang guru agama harus selalu siap untuk memimpin setiap acara keagamaan, baik diminta ataupun tidak. ${ }^{20}$

\section{Simpulan}

Pendidik merupakan tenaga profesional yang bertugas merencanakan dan melaksanakan proses pembelajaran, dialah orang yang berusaha membimbing, meningkatkan, menyempurnakan, dan mensucikan hati anak didik sehingga menjadi dekat dengan khaliqnya. Tidak hanya itu, pendidik adalah seorang yang di samping memiliki pekerjaan mengajar, namun yang lebih penting ia ikut serta bertanggung jawab atas untuk membantu anak didiknya mencapai kedewasaan. Pendidik dalam bahasa Inggris disepadankan dengan kata teacher, instructor, lecturer, tutor dan educator. Sedangkan dalam Bahasa Arab, pendidik disepadankan dengan kata al-Alim (jamak ulama) atau alMu'allim, al-mudarris dan al-Muaddib. Namun al-Mu'allim atau al-Alim lebih banyak dari penggunaan kata al-Mudarris.

Kedudukan pendidik berada di urutan ke empat, setelah Tuhan, nabi dan orang tua. Guru adalah pendidik di lingkungan sekolah. Ada hak dan kewajiban yang dimiliki oleh guru. Diantara hak guru adalah penerimaan gaji. Beberapa ulama menolak adanya gaji guru, namun ulama lain memperbolehkan gaji apabila guru sebagai jabatan profesi.

${ }^{20}$ Abdul Aziz, Guru PAI dan Tantangan Masa Depan, dalam Himmah, Vol. IV No 09 Edisi Januari-April 2003, hlm. 55-58.

$184 \mid$ JURNAL LISAN AL-HAL 
Seorang pendidik dituntut untuk memiliki beberapa sifat khusus, diantaranya; 1) Zuhud dan mengajar karena Allah. 2) Kesucian pendidik. 3) Ikhlas.4) Bijaksana.5) Berpenampilan kharismatik dan tenang 6 . Memahami kejiwaan anak, cita-cita, dan pemikirannya agar tidak salah bersikap kepadanya. 7) Menguasai materi pelajaran dan terus mengembangkan penelitian. Di samping itu, pendidik diharuskan juga memiliki beberapa strategi, yaitu: 1) melanjutkan pendidikan keguruan. 2) mendalami mata pelajaran yang diampu. 3) belajar mengenai strategistrategi pembelajaran yang tepat guna. 4) memiliki kepercayaan bahwa pendidik mampu memberi perbedaan bagi keberlangsungan kehidupan anak didiknya. 5) melakukan refleksi dan mengkritisi praktik-praktik pembelajaran pendidik sendiri. 6) Riset terhadap cara mengajar pendidik sendiri. 7) mempelajari kebudayaan di daerah tempat pendidik mengajar.

\section{DAFTAR PUSTAKA}

Al-Abrasyi, M. Atiyah, Dasar-Dasar Pokok Pendidikan Islam(terj). Jakarta: Bulan Bintang. 1993.

Al-Ghazali, Imam, Ilmu dan Manfaatnya, Terj. Achmad Sunarto, Surabaya: Karya Agung. 2010.

---------, Ihya' Ulumuddin, Juz I, Terj. Moh. Zuhri, Semarang: Asy-Syifa'. 2003.

Al-Qadhi, Ahmad Arafat al-Qadhi, Al-Fikr at-Tarbawi indal Mutakallimien al-Muslimin, Mesir: al-Hai'ah al-Misriyah. 1996.

Aziz, Abdul. "Guru PAI dan Tantangan Masa Depan”, Himmah, Vol. IV No 09 Edisi Januari-April. 2003.

Daradjat, Zakiah, Ilmu Pendidikan Islam, Jakarta: Bumi Aksara. 2000.

----------, Kepribadian Guru, cet ke 4, Jakarta: Bulan Bintang. 2005.

Echols, Jhon M \& Sadily, Hasan, Kamus Inggris Indonesia, cet. Ke-18, Jakarta: Balai Pustaka. 1980.

Nata, Abuddin, Filsafat Pendidikan Islam, Jakarta: Gaya Media Pratama. 2005.

---------, Prespaktif Islam Tentang Pola Hubungan Guru-Murid, Jakarta: Raja Grafindo. 2001.

-----------, Pemikiran Para Tokoh Pendidikan Islam, cet ke 2, Jakarta: Raja Grafindo Persada. 2001.

Nizar, Samsul, Memperbincangkan Dinamika Intelektual dan Pemikiran HAMKA Tentang Pendidikan Islam, Jakarta: Kencana. 2008.

Ormrod, Jeanne Ellis, Educational psycology Developing Learned, Terj. Wahyu Indianti, Jakarta: Erlangga. 2008. 
Qamar, Mujammil. Epistemologi Islam- Dari Metode Rasional hingga metode Kritik. Jakarta: Penerbit Erlangga. 2005.

Ramayulis, Ilmu Pendidikan Islami, cet. ke 10, Jakarta: Kalam Mulia. 2001.

Rosyada, Dede. Paradigma Pendidikan Demokratis. Prenada Media: Jakarta. 2004.

Rosyadi, Khoiron, Pendidikan Profetik, Yogyakarta: Pustaka Pelajar. 2004.

Sahrodi, Jamali, Membedah Nalar Pendidikan Islam, Yogyakarta: Pustaka Rihlah. 2005.

Suparlan, Guru Sebagai Profesi, Yogyakarta: Hikayah. 2006.

Syalabi, Ahmad. At-Tarbiyah Wa Ta'lim cet. ke 8, Kairo: Maktabah AnNahdhotul Misriyah. 1986.

186 JURNAL LISAN AL-HAL 